\title{
Rozwój systemów wykorzystujących akumulację energii $w$ transporcie szynowym
}

\begin{abstract}
$W$ artykule przedstawiono nowe rozwiqzania $w$ zakresie wykorzystania akumulacji energii w systemach transportu szynowego. Na szczególnq uwage zastuguja nowe konstrukcje japońskich wagonów silnikowych o napędzie hybrydowym. Pierwsze trzy takie pojazdy zostały wprowadzone do eksploatacji przez East Japan Railway Company 31 lipca 2007
\end{abstract}

\section{Wstęp}

Napędy hybrydowe nie są, wbrew temu, co się sądzi, pomysłem nowym. Pierwsze zastosowania tych napędów datują się na początek ubiegłego stulecia, przy czym początkowo ograniczały się one do pojazdów drogowych. W ostatnich latach daje się zaobserwować zwiększone zainteresowanie napędami hybrydowymi przez producentów taboru kolejowego. Niniejszy artykuł stanowi próbę przedstawienia tendencji rozwojowych w tym zakresie w kontekście rosnących cen nośników energii i troski o środowisko naturalne.

\section{Napędy hybrydowe w pojazdach transportu drogowego}

Pierwsze próby skonstruowania pojazdów hybrydowych datują się na początek ubiegłego stulecia, kiedy to w Belgii i w Stanach Zjednoczonych powstały pierwsze prototypy takich pojazdów. Przyczyna ich skonstruowania była prozaiczna - w owym czasie moc jednostkowa silników spalinowych i parowych była bardzo niska, w związku z tym wspomagający napęd silnikiem elektrycznym, zasilanym $z$ akumulatora, poprawiał własności trakcyjne pojazdu i jego osiagi. W tym kierunku szły konstrukcje belgijskiego konstruktora i producenta samochodów Piepera (pojazdy komercyjne budowane na podstawie jego patentu w latach 1906-1912) oraz Amerykanina H. Piepera (patent na pojazd hybrydowy udzielony w 1905 roku). W 1910 roku powstał prototyp hybrydowej ciężarówki, na bazie którego w Filadelfii w USA budowano seryjnie hybrydowe pojazdy ciężarowe aż do roku 1918. W międzyczasie konstrukcje silników spalinowych zostały w znacznym stopniu udoskonalone, co wyeliminowało z rynku pojazdy o napędzie hybrydowym. Ponowne zainteresowanie napędami alternatywnymi datuje się na przełom lat sześćdziesiątych i siedemdziesiątych XX wieku. Powstają w tym okresie pierwsze eksperymentalne pojazdy hybrydowe
- można tu wspomnieć o patencie amerykańskiej firmy TRW (1971), pojazdach GM512 (1969), VW Taxi (1974), Buicku Skylark, przebudowanym na pojazd hybrydowy przez Wouka i Rosena (1974). Inspiracją do wielu prac był drastyczny wzrost cen ropy naftowej w I połowie lat siedemdziesiątych oraz konieczność ograniczenia emisji spalin przez pojazdy samochodowe, szczególnie w Kalifornii. W USA powstało w tym okresie kilka aktów prawnych, stymulujących bezpośrednio lub pośrednio rozwój napędów hybrydowych $[1,7,12,14]$.

Ponowny wzrost zainteresowania hybrydami przypada na lata dziewięćdziesiąte - w Stanach Zjednoczonych realizowany jest program Partnership for a New Generation of Vehicles, finansowany ze środków amerykańskiej „Wielkiej Trójki” i Departamentu Transportu. Mniej więcej w tym samym okresie Toyota podejmuje działania na rzecz uruchomienia produkcji pojazdów niskoemisyjnych, uwieńczone uruchomieniem w 1997 roku produkcji (początkowo na rynek japoński) samochodu osobowego Toyota Prius. Pierwsze wyniki sprzedaży są zachęcające - do końca roku sprzedano w Japonii ok. 18000 tych pojazdów. W tym samym roku Audi uruchamia produkcję pierwszego europejskiego samochodu hybrydowego (Audi Duo, bazujący na konstrukcji Audi Avant). Brak zainteresowania tą konstrukcją na rynku skłonił producentów europejskich do rozwijania konstrukcji napędów opartych na silnikach wysokoprężnych. W roku 1999 na rynku amerykańskim pojawia się hybrydowa Honda Insight, a rok później - Toyota Prius. W roku 2002 Honda wprowadza do sprzedaży model Civic Hybrid. Dwa lata później zmodernizowana Toyota Prius II zostaje samochodem roku w plebiscycie organizowanym przez Motor Trend Magazine i pojawia się na rynku europejskim $[1,12,14,15]$. Sukces seryjnie produkowanych pojazdów o napędzie hybrydowym skłonił czołowe koncerny samochodowe do podjęcia intensywnych prac konstrukcyjnych i aktualnie mo- 
żemy napędy hybrydowe spotkać w ofercie większości liczących się producentów światowych.

\section{Systemy i pojazdy wykorzystujące akumulację energii rekuperacji w kolejnictwie}

Pojazdy szynowe, wyposażone w napęd hybrydowy, można zdefiniować jako pojazdy, wyposażone w pokładowe systemy akumulacji energii, usytuowane pomiędzy pierwotnym źródłem energii (z reguły trakcyjnym silnikiem wysokoprężnym) a przekładnia, dostarczająca moment obrotowy na napędzane zestawy kołowe pojazdu. Zastosowanie układów hybrydowych jest atrakcyjne $\mathrm{z}$ punktu widzenia możliwości wykorzystania energii rekuperacji, która pojawia się podczas hamowania pojazdu. W trakcji elektrycznej rekuperowana energia jest przekazywana do sieci trakcyjnej, o ile na tym samym, lub na pobliskim odcinku zasilania znajduje się inny pojazd trakcyjny, pobierający energię $z$ sieci. W przypadku, gdy nie ma możliwości przekazania energii rekuperowanej innemu pojazdowi pojazd przechodzi do klasycznego trybu hamowania, co powoduje zamianę energii kinetycznej pojazdu na energię cieplną, rozpraszaną $w$ otoczeniu. Pojazd hybrydowy wyposażony jest w zasobnik energii (na ogół baterię akumulatorów), w którym energia rekuperacji zostaje zmagazynowana $\mathrm{w}$ celu jej wykorzystania podczas rozruchu. Rozwiązaniem alternatywnym jest zastosowanie stacjonarnych zasobników energii, usytuowanych w pobliżu linii kolejowej, do których energia rekuperowana zostaje przekazana, względnie wykorzystanie układów przekształtnikowych w podstacji trakcyjnej, które energię rekuperacji zwracają do sieci energetycznej. Każde z powyższych rozwiązań posiada określone wady zasobnik energii na pojeździe zwiększa jego ciężar i pogarsza własności dynamiczne pojazdu. Stacjonarne zasobniki energii muszą być usytuowane $\mathrm{w}$ relatywnie małych odległościach, szczególnie na liniach charakteryzujących się dużym natężeniem przewozów. Z drugiej strony mają one korzystny wpływ na „wygładzenie" przebiegów prądowo-napięciowych w sieci trakcyjnej i na zniwelowanie ,pików” mocy pobieranej przez podstacje trakcyjne $\mathrm{z}$ sieci energetycznej. Zastosowanie układów przekształtnikowych implikuje wzrost nierównomierności poboru mocy.

Dotychczas próby zastosowania stacjonarnych zasobników energii nie wykraczały poza fazę pojedynczych instalacji, choć pierwsze koncepcje pochodzą jeszcze z początku XX wieku (Góry Skaliste, USA). Dwie prototypowe podstacje akumulujące nadwyżki energii rekuperacji, wyposażone w bezwładniki (koła zamachowe) były eksploatowane od pierwszej połowy lat osiemdziesiątych na linii Keihin w Japonii. Jedna z nich funkcjonuje do chwili obecnej $[2,3]$. Na zastosowanie stacjonarnej podstacji akumulującej nadwyżki energii rekuperacji z bezwładnikami wykonanymi w technologii włókien węglowych zdecydował się ostatnio zarząd metra w Nowym Jorku [4]. Stacjonarne podstacje akumulacyjne budowano także na bazie akumulatorów elektrochemicznych i tzw. kondensatorów dwuwarstwowych $[5,8,10,18]$.

Zastosowania akumulacji energii na pojeździe początkowo wiązały się z koncepcją napędu elektrycznego, w którym silniki trakcyjne zasilane były $\mathrm{z}$ baterii akumulatorów. Pierwsze próby budowy pojazdów akumulatorowych nie należały do udanych z uwagi na brak dostatecznie zaawansowanych technologicznie akumulatorów - były one zbyt ciężkie z uwagi na niskie wartości energii właściwej i mocy właściwej charakteryzujące tanie akumulatory ołowiowe i zasadowe akumulatory niklowo-żelazowe, w związku $\mathrm{z}$ tym zasięg takich pojazdów był niedostateczny. Przykładem takich konstrukcji, które nie sprawdziły się w eksploatacji była polska lokomotywa EPA 42-01, przebudowana $\mathrm{w}$ roku $1987 \mathrm{z}$ lokomotywy manewrowej SM 42. Lokomotywa miała być wykorzystywana do prowadzenia pociagów sieciowych w tunelu średnicowym w Warszawie. W pojeździe tym silnik trakcyjny został zastapiony baterią akumulatorów. Wyniki badań eksploatacyjnych nie potwierdziły założeń projektowych, jakość akumulatorów była niedostateczna i w efekcie prototyp nie został ostatecznie wprowadzony do normalnej pracy na PKP [19].

Większy sukces odniosły konstrukcje pojazdów szynowych, wykorzystujące hybrydowy napęd elektryczno-bateryjny. Palma pierwszeństwa w tej kategorii należy do Stanów Zjednoczonych. W roku 1928 firma Kennecott Copper złożyła zamówienie na 4 lokomotywy elektryczne wyposażone w dużą baterię akumulatorów Ni-Fe. Przepracowały one pomyślnie kilka dekad. Zasilanie odbywało się z sieci trakcyjnej o napięciu $750 \mathrm{~V}$, a akumulatory umożliwiały krótkotrwałe zwiększenie mocy (szczególnie podczas rozruchu) i pracę na odcinkach niezelektryfikowanych [23].

W metrze londyńskim od roku 1936 były eksploatowane lokomotywy z takim właśnie układem napędowym. Przeznaczone były do prac serwisowych w tunelach metra. W miejsce wyeksploatowanych lokomotyw w latach 50., 60. i 70. dostarczane były nowsze pojazdy. Aktualnie metro londyńskie dysponuje pięcioma takimi pojazdami, wyprodukowanymi w roku 1970 (rys. 1).

Na przełomie lat 70. i 80. koleje niemieckie eksploatowały wagony silnikowe o napędzie elektrycznoakumulatorowym [13]. Na początku lat osiemdziesiątych hybrydowe pojazdy metra, wyposażone w akumulatory inercyjne (koła zamachowe) wprowadziło do eksploatacji metro w Nowym Jorku [9].

W roku 1986 czechosłowacki producent pojazdów szynowych, ČKD, wyprodukował prototyp hybrydowej lokomotywy manewrowej, oznaczonej symbolem DA 600, zasilanej silnikiem wysokoprężnym o mocy 190 kW. 4 elektryczne silniki trakcyjne tej 


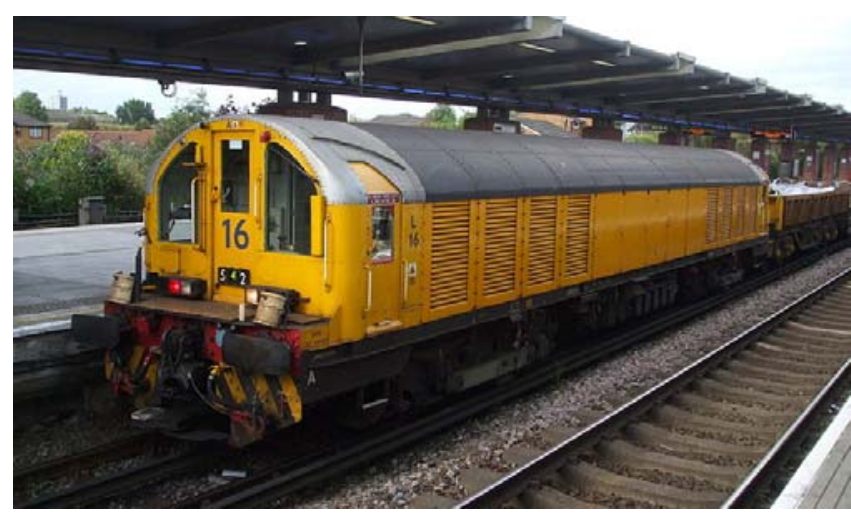

2ys. 1. Lokomotywa L16 o napędzie elektryczno-bateryjnym, eksploatowana przez metro londyńskie. Źródło: http://en. wikipedia.org/wiki/File:Battery_loco_16_at_West_Ham.JPG (odczyt z dnia 2.05.2010)

lokomotywy miały moc ciagłą $360 \mathrm{~kW}$ i były zasilane jednocześnie przez generator, napędzany silnikiem spalinowymi i przez baterię akumulatorów. Akumulatory były doładowywane $\mathrm{w}$ trakcie pracy silnika lokomotywy, a także podczas hamowania rekuperacyjnego. Mogły być także doładowywane w czasie postoju lokomotywy z zewnętrznego źródła energii. Po zakończeniu testów lokomotywa została przekazana do Ołomuńca, gdzie była pomyślnie eksploatowana przez 10 lat. Produkcji seryjnej tych lokomotyw nie udało się uruchomić ze względu na niewystarczające moce produkcyjne czechosłowackich firm wytwarzających akumulatory i brak możliwości w zakresie importu zaopatrzeniowego [21].

Ciekawym rozwiązaniem konstrukcyjnym są francuskie zespoły trakcyjne Autorail à Grande Capacité, produkowane od roku 2004 w różnych wariantach przez kanadyjskiego Bombardiera jako trakcyjne zespoły XGC o napędzie spalinowym (seria $X$ 76500), dwusystemowe zespoły elektryczne ZGC (seria Z 27500) oraz dwumodalne zespoły BGC (napęd spalinowy + napęd elektryczny $1500 \mathrm{VDC}$ - seria B 81500) i dwumodalne zespoły BGC $\mathrm{z}$ napędem spalinowym i napędem elektrycznym dwusystemowym $1500 \mathrm{VDC} / 25 \mathrm{kV}$ AC [22].

Umiarkowanym zainteresowaniem kolei amerykańskich cieszą się hybrydowe lokomotywy firmy Green Power, produkowane od 2005 roku przez kanadyjską firmę Railpower Technologies. Firma oferuje także usługi $\mathrm{w}$ zakresie przebudowy istniejących spalinowych lokomotyw manewrowych na wersje hybrydowe [23]. Zgodnie $\mathrm{z}$ danymi firmy zastosowanie napędu hybrydowego zapewnia ograniczenie emisji substancji szkodliwych do $90 \%$ i ograniczenie zużycia paliwa do $60 \%$. Pojazdy te zostały szczegółowo opisane w periodyku krajowym [24]. Ciekawym rozwiązaniem są lokomotywy Raipower serii Genset, w których źródłem napędu są małe silniki spalinowe; ich liczba wynosi, w zależności od modelu, od 2 do 4. Komputer pokładowy załącza odpowiednią liczbę silników w zależności od chwilowego zapotrzebowa- nia na moc. Jedna taka lokomotywa, w wersji dwusilnikowej, została wyposażona $\mathrm{w}$ baterię akumulatorów i uzyskała oznaczenie RP20BH. Łącznie firma Railpower wyprodukowała w latach 2004-2010 około 190 lokomotyw, z których 66 - to lokomotywy hybrydowe o mocy 1000 i $2000 \mathrm{KM}$, a ponad 120 - to wielosilnikowe lokomotywy Genset [25].

Prototyp lokomotywy hybrydowej zbudowała także firma General Electric. Lokomotywy hybrydowe GE mają stanowić uzupełnienie aktualnie oferowanej serii GE Evolution [23].

\section{Nowe hybrydowe pojazdy szynowe produkcji japońskiej}

Podobnie, jak w przypadku pojazdów samochodowych, również dziedzinie hybrydyzacji pojazdów szynowych konstruktorzy i producenci japońscy stają się liderami światowymi. Ich dziełem jest pierwszy na świecie hybrydowy spalinowy wagon silnikowy, który po zakończeniu testów rozpoczął dwa lata temu normalną pracę eksploatacyjną. Producentem pojazdu jest firma Hitachi, która prace, związane z zastosowaniem napędów hybrydowych w kolejnictwie podjęła już $\mathrm{w}$ roku 2001 [26]. Opracowany szeregowy hybrydowy układ napędowy jest wynikiem współpracy firmy Hitachi z działem badawczym East Japan Railway Company (jednej z 7 spółek kolejowych, wchodzących w skład grupy Japan Railways). Hybrydowy układ napędowy obejmuje silnik wysokoprężny o mocy $331 \mathrm{~kW}$, napędzający trójfazowy generator elektryczny o mocy ciagłej $270 \mathrm{~kW} / 615 \mathrm{~V}$ (rys. 2). Energia elektryczna, wytworzona przez generator, jest przekazywana do przekształtnika, z pośrednim obwodem prądu stałego, w skład którego wchodzi wysokowydajna bateria akumulatorów litowo-jonowych. Falownik typu VVVF zasila 2 silniki trakcyjne prądu przemiennego o mocy ciągłej $95 \mathrm{~kW}$ każdy. Układ sterowania zapewnia możliwość odzysku energii kinetycznej podczas hamowania wagonu [26, 27].

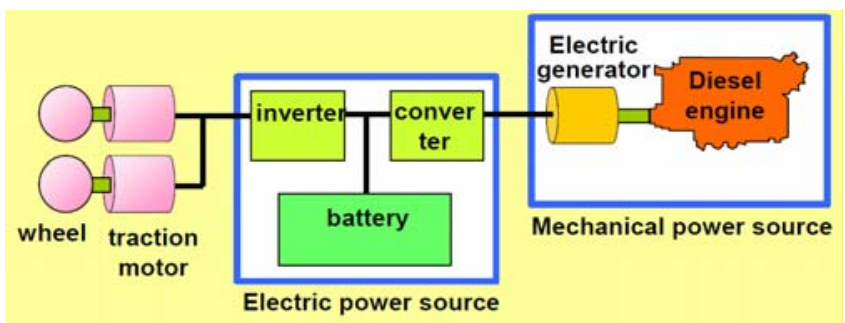

Rys. 2. Szeregowy hybrydowy układ napędowy wagonu silnikowego JR East [27]

Badania układu napędowego, przeprowadzone podczas jazd próbnych testowego wagonu silnikowego o nazwie NE Train (New Energy Train), wykazały korzystne własności układu w zakresie zużycia paliwa, niezawodności i trwałości układu akumulacji energii oraz możliwości zastosowania układu w normalnych warunkach eksploatacyjnych. W oparciu o 
wyniki badań JR East złożyły zamówienie na 3 hybrydowe wagony silnikowe i po ich dostarczeniu przez producenta w kwietniu 2007 roku rozpoczęto normalną eksploatację w dniu 31 lipca 2007 r., jednocześnie nadając nowym wagonom oznaczenie Kiha E200 DEMU (diesel electric multiple unit) [26].

Wygląd zewnętrzny wagonu silnikowego przedstawiono na rys. 3 . Podstawowe dane techniczne wagonu [28]:

\begin{tabular}{|c|c|}
\hline Okres eks & \\
\hline Liczba wagonów w eksploat & atacji \\
\hline Konfiguracja & \\
\hline & dynczy wagon silnik \\
\hline iczba miejsc dla pasażerów & 117 \\
\hline & (46 miejs \\
\hline Linia & Kuc \\
\hline & stal merazew wia \\
\hline Wymia & $19500 \times 2920 \mathrm{~mm}$ \\
\hline Prędkość maksymalna & $100 \mathrm{~km} / \mathrm{h}$ \\
\hline
\end{tabular}

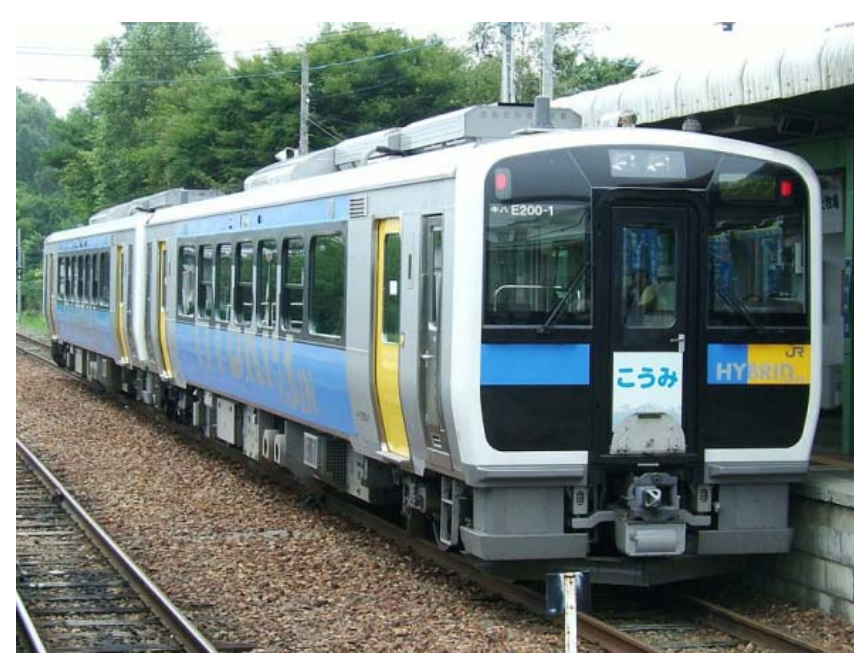

Rys. 3. Wagon silnikowy KiHa E200 kolei JR East z napędem hybrydowym. Źródło: http://en.wikipedia.org/wiki/File: JREast-kihaE200-1.jpg

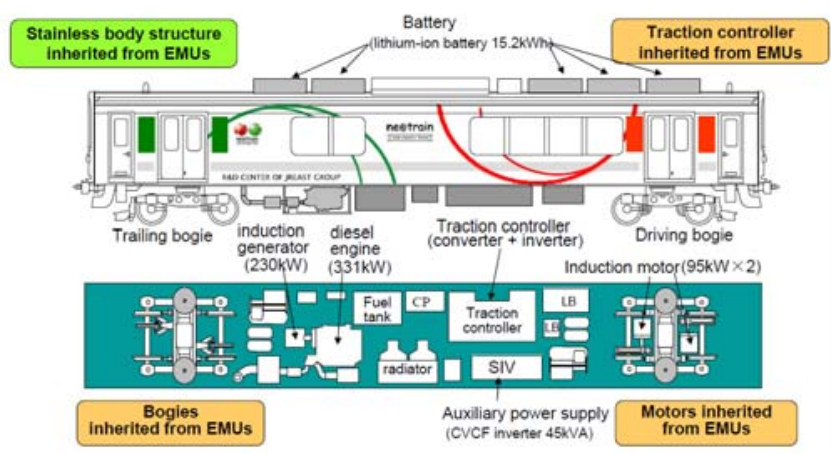

Rys. 4. Rozmieszczenie elementów układu napędowego w pojeździe [27]

System sterowania obejmuje układy kontroli poprawności działania poszczególnych obwodów elektrycznych oraz kontroli stopnia naładowania akumulatorów. W celu poprawy niezawodności systemu ma- gazynowania energii baterię akumulatorów podzielono na dwie odrębne funkcjonalnie części. W zależności od stopnia naładowania baterii i prędkości pojazdu regulowana jest moc silnika spalinowego, zgodnie $\mathrm{z}$ algorytmem zapewniającym utrzymanie właściwego stopnia naładowania akumulatorów i minimalizację zużycia paliwa:

a) w celu obniżenia poziomu hałasu i zmniejszenia zużycia paliwa silnik spalinowy jest wyłączany podczas postoju pojazdu;

b) rozruch pojazdu odbywa się kosztem energii zmagazynowanej w baterii akumulatorów (przy wyłączonym silniku spalinowym);

c) przy prędkości ok. $25 \mathrm{~km} / \mathrm{h}$ uruchamiany jest silnik trakcyjny, który za pośrednictwem generatora napędza silniki trakcyjne i doładowuje baterię akumulatorów;

d) podczas hamowania odzyskowego silnik spalinowy jest wyłączany, a energia rekuperowana doładowuje baterię akumulatorów;

e) gdy podczas hamowania rekuperacyjnego stopień naładowania baterii osiagnie maksimum, uruchamiane jest hamowanie silnikowe, aby zapobiec przeładowaniu baterii.

Schemat układu sterowania przedstawiono na rys. 5 , a schematy przepływów mocy $\mathrm{w}$ różnych fazach cyklu jazdy - na rys. 6 .

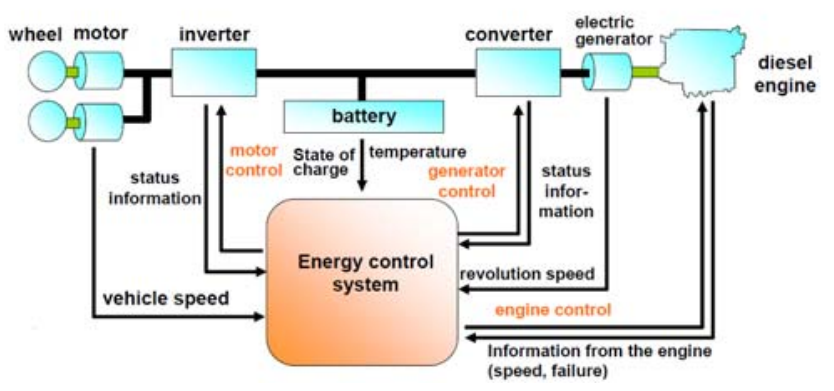

Rys. 5. Schemat funkcjonalny układu sterowania [27]

Pojazd wyposażony jest w nastawnik jazdy i układ kontroli trakcji zaadaptowany $\mathrm{z}$ seryjnie produkowanych przez firmę Hitachi zespołów trakcyjnych. Dodatkowym elementem nastawnika jest tzw. gradientprediction control system (system sterowania oparty na przewidywaniu profilu pionowego). System automatycznie rozpoznaje chwilowe położenie pojazdu na odcinku linii kolejowej i na tej podstawie przewiduje zmiany profilu pionowego, w wyniku czego następuje odpowiednia modyfikacja algorytmu sterowania układem zarządzania energią:

a) podczas jazdy po spadku w reżimie silnikowym lub podczas jazdy wybiegiem priorytetowo wykorzystywana jest energia $\mathrm{z}$ baterii akumulatorów; podczas hamowania $\mathrm{w}$ maksymalnym stopniu stosowany jest odzysk energii kinetycznej; 
b) na wzniesieniach i na odcinkach płaskich rozszerzany jest przedział wartości określających stopień naładowania baterii, umożliwiających rozpoczęcie ładowania/rozładowywania baterii akumulatorów.

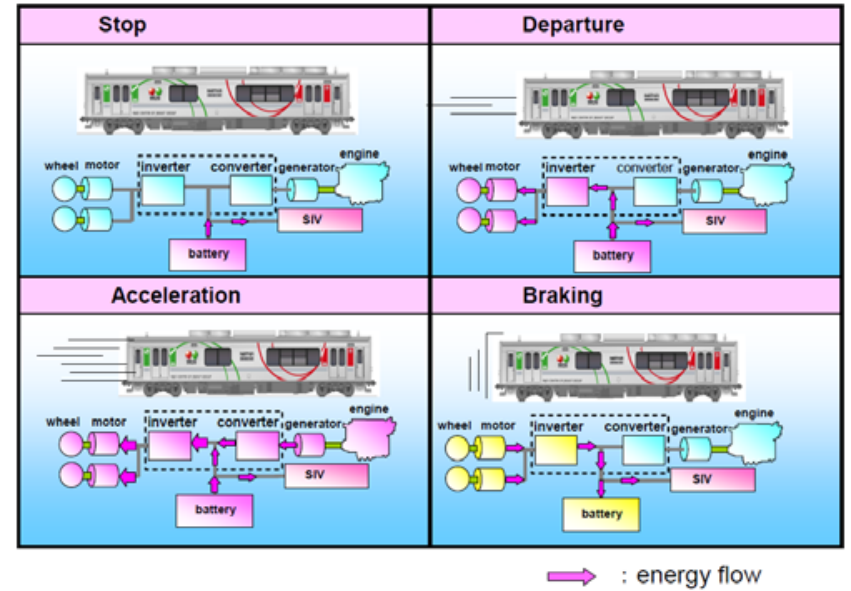

Rys. 6. Schemat przepływów energii w reżimach postoju, rozruchu, przyspieszania i hamowania [27]

Zespół akumulatorów został umieszczony na dachu pojazdu. Składa się on z 16 modułów o łącznej pojemności 15,2 Ah, łącznej rezystancji wewnętrznej $144 \mathrm{~m} \Omega$ i gęstości mocy $3 \mathrm{~kW} / \mathrm{kg}$. Masa pojedynczego modułu wynosi ok. $20 \mathrm{~kg}$, przy rozmiarach zewnętrznych 540 x $260 \times 160 \mathrm{~mm}$ (DxSxW). Zakładana żywotność baterii wynosi 8 lat, przy zakładanym okresie eksploatacji wagonu silnikowego, szacowanym na 15 lat [27].

Oszczędności energii, wynikające z zastosowania napędu hybrydowego, podczas testów wynosiły od kilku do ok. $20 \% \mathrm{w}$ zależności od profilu pionowego linii, na której prowadzono badania (liczba kilometrów przejechanych na jednostce objętości paliwa wynosiła $1,7-2,3 \mathrm{~km} / \mathrm{dm}^{3}$ ). Zgodnie $\mathrm{z}$ oczekiwaniami najmniejsze oszczędności uzyskiwano na podjazdach, największe oszczędności uzyskano na odcinkach linii o profilu płaskim. Emisja substancji szkodliwych zmniejszyła się dzięki optymalizacji warunków pracy silnika spalinowego(praca silnika $\mathrm{w}$ wąskim przedziale zmienności prędkości obrotowych) oraz dzięki zmniejszeniu zużycia paliwa, wynikającemu z zastosowania napędu hybrydowego. Emisja węglowodorów została zredukowana do poziomu $13,3 \% \mathrm{w}$ porównaniu z napędem „klasycznym”, emisja tlenków azotu do poziomu $40 \%$, zaś emisja sadzy - do poziomu $43,7 \%$. Jednocześnie poprawiły się własności dynamiczne pojazdu i, zdaniem badaczy, są one obecnie zbliżone do parametrów bliźniaczego elektrycznego zespołu trakcyjnego E 231 [27].

Aktualnie w ramach projektu ne@train prowadzone są badania kolejnego prototypu wagonu silnikowego, wyposażonego w baterię ogniw paliwowych, zasilanych gazowym wodorem. Na rys. 7 przedstawiono zbiornik wodoru (zdjęcie po lewej) i moduł ogniw paliwowych(zdjęcie prawe).
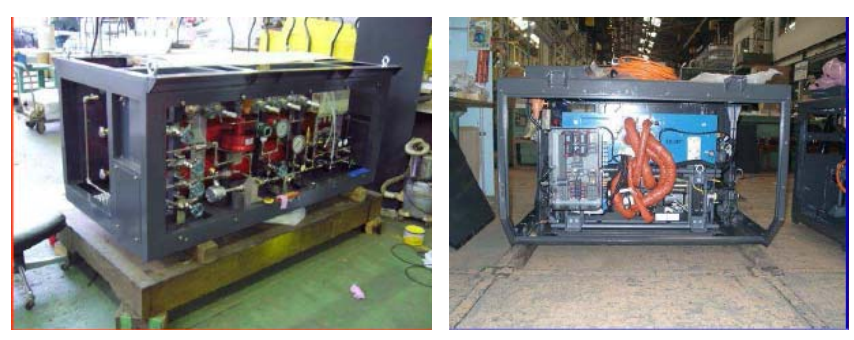

Rys. 7. Zbiorniki wodoru (po lewej) moduł ogniw paliwowych (po prawej) [27]

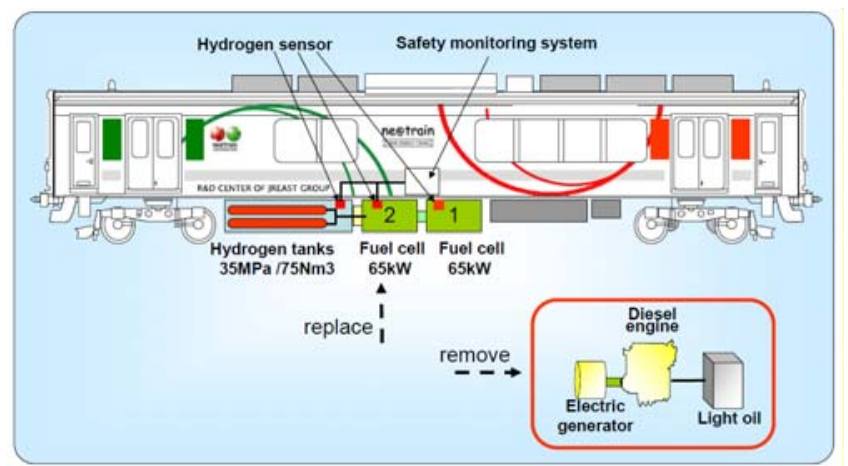

Rys. 8. Modyfikacja układu pojazdu związana z zastosowaniem ogniw paliwowych [27]

Na rysunku 8 przedstawiono zasadnicze zmiany w konstrukcji pojazdu, związane $\mathrm{z}$ zastosowaniem ogniw paliwowych. Ze skrzyń, zainstalowanych pod pudłem wagonu zostały usunięte silnik spalinowy ze zbiornikiem paliwa i z generatorem elektrycznym, w ich miejsce zainstalowano wysokociśnieniowe zbiorniki zawierające $75 \mathrm{Nm}^{3}$ wodoru pod ciśnieniem 35 $\mathrm{MPa}$ oraz dwa moduly ogniw paliwowych o mocy nominalnej po $65 \mathrm{~kW}$ każdy. Z uwagi na potencjalne zagrożenie, jakie niesie zastosowanie gazowego wodoru, w skrzyniach aparatowych zainstalowano system czujników - detektorów wodoru, podłączonych do systemu monitorowania bezpieczeństwa. Zmodyfikowany system sterowania przepływem mocy pokazano na rys. 9 .

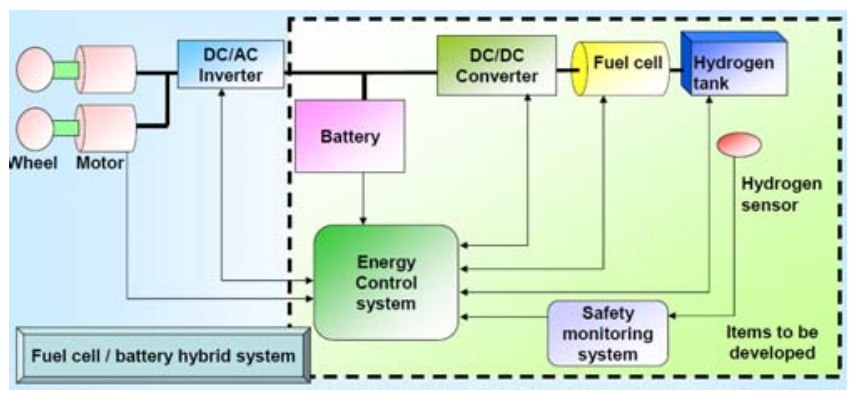

Rys. 9. Modyfikacja systemu sterowania przepływem mocy związana z zastosowaniem ogniw paliwowych [27]

$\mathrm{Z}$ uwagi na niskie temperatury robocze ogniwa paliwowego $\left(\sim 100^{\circ} \mathrm{C}\right)$ i dobrą dynamikę pracy podjęto decyzję o zastosowaniu ogniw paliwowych z polimerowym elektrolitem (PEMFC).

Firma Hitachi opracowała także, we współpracy z kolejami brytyjskimi, hybrydowy układ napędowy, przeznaczony dla spalinowych lokomotyw liniowych i 
dla zespołów trakcyjnych. Prototypowy układ hybrydowy został zamontowany w pociagu dużych prędkości, eksploatowanym w Wielkiej Brytanii. Pociąg testowy, nazwany V-Train 2, przeszedł serię testów, mających wykazać efektywność zastosowania nowego typu układu napędowego. Pod względem funkcjonalnym układ ten jest bardzo podobny do rozwiązań zastosowanych w opisanym wyżej wagonie silnikowym.

\section{Podsumowanie}

Ograniczone ramy artykułu nie pozwalają na bardziej szczegółowe omówienie przedstawionych rozwiązań konstrukcyjnych napędów alternatywnych $\mathrm{w}$ kolejnictwie. Wydaje się, że tendencje w zakresie wprowadzania napędów hybrydowych w kolejnictwie są bardzo wyraźne, szczególnie w kontekście osiągnięć amerykańskich (lokomotywy manewrowe) i japońskich. Warto dodać, że w literaturze przedmiotu znaleźć można szereg informacji o kolejnych operatorach kolejowych wprowadzających lub zamierzających wprowadzić w najbliższej przyszłości pojazdy szynowe $\mathrm{z}$ napędami alternatywnymi. Również producenci europejscy (Alstom, Bombardier i in.) prowadzą intensywne prace badawcze i konstrukcyjne, mające na celu wdrożenie do praktyki eksploatacyjnej nowych napędów. Kilka lat temu na wystawie Innotrans w Berlinie można było oglądać prototypowy zespół trakcyjny Corradia Lirex firmy Alstom, wyposażony w zasobnik energii. Sygnały o wprowadzaniu nowych napędów alternatywnych dochodzą także od producentów tramwajów - przykładem tego mogą być przeprowadzone kilka lat temu w Warszawie badania tramwaju $\mathrm{z}$ zainstalowanym zasobnikiem energii, mogącego poruszać się na krótkich odcinkach niezelektryfikowanych. Wobec rosnących cen energii i coraz lepszych parametrów zasobników energii rozwój systemów wykorzystujących akumulację energii w transporcie szynowym wydaje się być nieunikniony.

\section{Lit e r a t u ra}

[1] History of Hybrid Vehicles | Hybrid Cars. http://www.hybridcars.com/history/history-of-hybridvehicles.html (2.05.2010).

[2] Maruyama N., Fly-wheel type electric railway energy saving substation, Japanese Railway Engineering, Vol. 21, No. 2, 1981.

[3] Sa toru S., Wayside and on-board storage can capture more regenerated energy, Railway Gazette International, 2.07.2007 (przedruk dostepny na stronie internetowej http://www.railwaygazette.com/news/single-

view/view/10/wayside-and-on-board-storage-can-capturemore-regenerated-energy.html-2.05.2010).

[4] New York orders flywheel energy storage, Railway Gazette International, 14.08 .2009 (przedruk dostępny na stronie internetowej http://www.railwaygazette. com/news/singleview/view/10/new-york-orders-fly-wheel-energy-storage.html $-2.05 .2010)$.

[5] Gunselmann W., Höschler P., Reiner G., Energiespeichereinsatz im Statbahnnetz Köln, Elektrische
Bahnen 98 (2000) z. 11-12.

[6] Pawetczyk M., Ocena korzyści zwiqzanych z zastosowaniem zasobników energii $w$ trakcji elektrycznej pradu statego, Materiaty Międzynarodowej Konferencji MET '2001, Gdańsk 2001.

[7] Pawetczyk M., Zasobniki energii $w$ transporcie możliwości zastosowań $i$ korzyści, Spedycja, Transport, Logistyka, $n r$ 3/2001.

[8] Baxter R., Energy storage: enabling a future for renewables? Renewable Energy World July-August 2002.

[9] Bowler M.E., Flywheel energy systems: Current status and future prospects, Magnetic Material Producers Association Joint Users Conference, 1997.

[10] Marshall J., Supercharging Ahead: Bay Area firms lead in race to develop high-tech device, San Francisco Chronicle, January 29, 1997.

[11] Energy Storage. Ultracapacitors and Batteries, A leaflet of the Argonne National Laboratory, Argonne, Illinois.

[12] Vo u k V., Pojazdy z napędem hybrydowym, Świat Nauki, nr 12, 1997.

[13] Rappenglück W., Pfister, F., Elektrischer Triebwagen für Fahrleitungs- und Batteriebetrieb, ETR (30) $9-1981$.

[14] Re uyl J.S., Schuurmans P.J., Policy Implications of Hybrid-Electric Vehicles, Final Report to NREL under Subcontract \# ACB-5-15337-01. April 22, 1996.

[15] Szumanowski A., Akumulacja energii w pojazdach, Wydawnictwa Komunikacji i Łaczności, Warszawa 1983.

[16] Mierzejewski L., Szelag A., Aktualne kierunki ograniczania zużycia energii elektrycznej $w$ transporcie kolejowym, Technika Transportu Szynowego, lipiec-sierpień 2004.

[17]Van Mierlo J., Van den Bossche P., Magget to G., Models of energy sources for EV and HEV: fuel cells, battery, ultracapacitors, flywheels and engine-generators, Journal of Power Sources 128 (2004) 7689.

[18] Lechner M., Re in er K., Einsatz eines Batterienspeichers bei einer Bergbahn, Elektrische Bahnen 93 (1995)

[19] Zapiski maszynisty - Pamiętnik maszynisty - bloog.pl. http://1435mm.bloog.pl/id, 2867584,title,EPA42,index.html? ticaid $=6 a 406(2.05 .2010)$

[20] London Underground battery-electric locomotives, Artykut w Wikipedii: http://en.wikipedia.org/wiki/London_Underground_battery-electric_locomotives (2.05.2010).

[21] V Japonsku se bude jezdit hybridním vlakem, http://www.zelpage.cz/zpravy/5014 (1.05.2010).

[22] Autorail $\dot{r}$ grande capacité, Artykut $w$ Wikipedii: http://en.wikipedia. org/wiki/Autorail_\%C3\%AO_grande_ capacit\%C3\%A9 (3.05.2010).

[23] Hybrid train, Artykut w Wikipedii: http://en.wikipedia. org/wiki/Hybrid_Locomotive (1.05.2010).

[24] Michnej M., Szkoda M., Wspótczesne rozwiqzania hybrydowych uktadów napędowych spalinowych pojazdów trakcyjnych, Technika Transportu Szynowego, nr 10/2007.

[25] RailPower's Green Goat Locomotives; Hybrids and Genset, Strona internetowa http://www.american-rails.com/greengoat-locomotives.html (4.05.2010).

[26] Tokuyama K., Shimada M., Terasawa K., Kan e ko T., Practical Application of a Hybrid Drive System for Reducing Environmental Load, Hitachi Review, Vol. 57), No. 1, (2008.

[27] Furuta R., Development of new energy train, 9th UIC Environment Coordinators Conference. Innovation Session: The Trains of the Future. Marseille 13th of October 2006, http://www.uic.org/spip.php? article1563.

[28] KiHa E200, Artykut w Wikipedii http://en.wikipedia.org/ wiki/KiHa_E200 (3.05.2010). 